by Messrs. McGill and Smith Ltd. The Potato Synonym Committee has also published its findings from the trial plots laid down in 1935, and the list of varieties with their synonyms may be obtained on application. Those interested in farming and wishing to keep in touch with the current work of the Institute, one of the chief objects of which is to supply unbiased information as to germination, variety and productive value of seed, are recommended to join the fellowship of the Institute, particulars of which can be obtained from the Secretary, National Institute of Agricultural Botany, Huntingdon Road, Cam. bridge.

\section{Soil Sterilisation}

A THrRD and enlarged edition of Bulletin No. 22, "Practical Soil Sterilisation", has been issued by the Ministry of Agriculture. As in former editions, the volume deals with the practical aspects of sterilising soil by means of heat and chemicals, both on a large scale in glasshouses and in small quantities for market garden and propagation work. The process of sterilising soil by steam is now widely practised, and the recent development of a new device, the 'Hoddesdon' pipe system, which overcomes many of the disadvantages of the older methods, called for a revised issue of the bulletin. The new system is composed of pipes laid in position separately and joined prior to turning on the steam, thus enabling a more efficient distribution of the heat than was possible with the tray, grid or spike methods, where small areas tended to remain untouched. In addition, the cost, namely, $£ 160$ per acre, compares favourably with other methods, and the labour is less arduous, so that from all points of view the new system can be recommended to the commercial grower with every confidence. All practical detajls are supplied in the bulletin, which may be obtained from H.M. Stationery Office or any bookseller, (1s. net).

\section{Oxidation-Reduction Potentials}

Following on hydrogen ion concentration, the subject of oxidation-reduction potentials has opened up a new field of investigation into the character of the media in which organisms flourish. Dr. L. F. Hewitt, in his "Oxidation-Reduction Potentials in Bacteriology and Biochemistry" (L.C.C., third edition, 1935), gives a very clear presentation of the theory as well as an account of the methods of measurement. The mechanisms underlying the action of respiratory pigments as well as the characteristics of certain bacterial culture media have been very profitably examined by this technique. A good deal of information has been derived from following the oxidation. reduction potential of the medium during the actual growth of the bacteria, and the findings have been supported by other methods of investigation. As a test method for defining the optimum conditions for growth, its further possibilities may be substantial. This little book will prove of great service to bacteriologists and biologists generally.

\section{Osborn Library at New York}

Is 1908, in the American Museum of Natural History, Prof. Henry Fairfield Osborn (see Nature of November 16, 1935) established the Osborn Library of Vertebrate Palæontology, presenting his personal library as a nucleus. To this the Museum added such volumes as it already possessed, its file of palæontological periodicals which it has kept up to date, and continued purchasing such new volumes as its funds made possible. As in any departmental library, however, the separata are the greatest needs of the worker, Prof. Osborn continued to turn over to the Osborn Library files of those papers which he received from his colleagues. Dr. Barnum Brown, curator of fossil reptiles in the Museum, asks that those who exchanged papers with Prof. Osborn during his life should continue to keep the Osborn Library on their lists, while others are invited to send copies of their papers. It will be at once a tribute to Prof. Osborn's memory and a service to fellow-workers since the Osborn Library is open to all.

\section{Congress of Economic Etomology}

THE annual meeting of the Deutsche Gesellschaft für Angewandte Entomologie will be held in Frankfort-on-Main on May 13-16, when three major problems in economic entomology will be discussed, namely, the control of bedbugs, mosquitoes and pests of stored products. Leaders of discussions on these problems will be Mr. A. W. McKenny Hughes, of the British Museum (Natural History) and secretary of the Medical Research Council Bedbug Committee, Prof. E. Martini, of the Institute of Maritime and Tropical Diseases, Hamburg, and Mr. E. Bernfuss, technical manager of the Städtliche Lagerhaus of Vienna. It is felt that all three problems are of international importance and urgently require attention, and it is hoped that medical officers and others concerned in public health, professional entomologists, warehouse managers, manufacturing chemists interested in insecticides, and chemical engineers interested in fumigation equipment will attend the meeting. Full particulars of the meeting can be obtained from Dr. W. Rasch, Hermann Göring Ufer 3, Frankfurt (Main) 1.

\section{Conference of Overseas Industrial Medical Officers}

THE Annual Conference for Medical Officers in Industry Overseas will be held on July 16 at the London School of Hygiene and Tropical Medicine, in order that medical officers in industry on leave from the tropics may be able to meet their colleagues and discuss their problems. The main subject for discussion will be the prevention of disease, for example, the control of malaria and epidemic diseases in the tropics; water supplies; sewage and refuse disposal; housing; the keeping of records; and hygiene generally. Further information can be obtained from the Organising Secretary, Ross Institute of Tropical Hygiene, London School of Hygiene and Tropical Medicine, Keppel Street (Gower Street), London, W.C.1. 